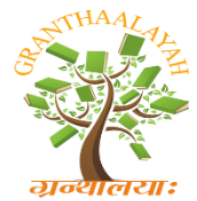

INTERNATIONAL JOURNAL OF RESEARCH GRANTHAALAYAH A knowledge Repository

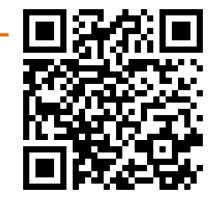

Management

\title{
EFFECT OF MATERIAL MANAGEMENT ON THE PERFORMANCE OF BENUE BREWERY INDUSTRY, NIGERIA
}

\author{
Adamu Garba *1 \\ ${ }^{*}$ Department of Business Administration, Nasarawa State University, Keffi, Nasarawa State
}

\begin{abstract}
This research work examined the effect of material management on the performance of Benue Brewery Industry, Nigeria using survey research design with a population of 242 respondents and a sample of 151. Data was collected using questionnaire and analyzed using descriptive statistics such as frequency, simple percentage and the relationship between the variables of the model was tested using multiple regression analysis. The result of the regression analysis shows that inventory control system and stock valuation have a positive and significant $(\mathrm{p}<0.05)$ effect on organizational performance. Lead time was negatively signed but the effect is statistically significant $(p<0.05)$. The researcher concludes that when properly carried out planned material management can bring about efficiency at workplace. The researcher recommends that, management of the Nigerian Brewery should bring an improvement in the lead time as it is will bring about acquiring and delivering the needed materials within the shortest time possible.
\end{abstract}

Keywords: Material; Management; Manufacturing; Performance; Benue; Nigeria.

Cite This Article: Adamu Garba. (2020). "EFFECT OF MATERIAL MANAGEMENT ON THE PERFORMANCE OF BENUE BREWERY INDUSTRY, NIGERIA.” International Journal of Research - Granthaalayah, 8(2), 228-234. 10.29121/granthaalayah.v8.i2.2020.213.

\section{Introduction}

An organization practices material management when they adopt certain methods necessary to ensure the smooth flow of materials needed in the day to day running of the organization. Thus, how well the organization functions depends on the quality of materials supplied. Management of organizations plays a very important role in ensuring that the right quality of materials are supplied to enable the company carry out its day to day activity. Materials management has been defined by Lee and Dobler (1997) the sum total of all the itineraries which leads to making available from outside the organizations the material need of such organization.

The principal goal of materials management is to guarantee that the correct material is available when it is needed with the lowest cost to the company (Jacobs, Chase, and Aquilano, 2009). The main aim of materials management is to make available an intermittent sequence of material need 
or raw materials. The productivity of any company will be greatly affected if the management of the company does not pay special attention to material management in the company. This is because, this is the lifeblood that holds the various components of manufacturing in any organization together and ensure that it will have all the necessary items needed to carry out its day to day activities. Successful implementation of material management concept in an organization leads to reduction in duplication of functions, improvement in delivery of materials among other benefits.

Over the years, the researcher has noticed that majority of companies in Nigeria and especially in the study area are faced with the problem of having the required level of materials such as raw materials which they need in order to effectively engage in production of goods and services to satisfy the market demands for such products and services (Ibegbulem and Okorie, 2005). This inability to effectively manage the flow of materials from the external environment into the company could be attributed to several reason ranging from management inefficiency in management of the supply chain for the products, inadequate working capital, harsh business environment among other factors.

To ensure an effective material management in a organization, the holistic installation and maintenance of an inventory control system which is a system that include all the chain from purchasing to warehousing. For an effective material management, stock valuation is paramount in determining the inherent worth of company's share. Most company's fail in material management because of the inability to manage lead time (Okoro, 2019). Thus, the initiation of inventory purchase and the time it gets delivered to the company is a huge determinant of the performance of an organization which is the actual output of the organization measured against it intended output.

The aforementioned problems have been extensively studied in many developed countries. However, due to the fact that the business environment of such countries are different from the one in the study area, the researcher thus examines the issue of material management and the effect it has on an organization using Nigerian Brewery, Makurdi Benue State as a case study. The main objective of the study is to examine the effect of material management on organizational performance in the manufacturing Sector in Nigeria with a particular reference to Nigerian Brewery, Makurdi Benue State, Nigeria. The specific objectives of the study however are to: examine the effect of inventory control system as a material management strategy on organizational performance in manufacturing Sector in Nigeria, investigate effect of Stock valuation on organizational performance in manufacturing Sector in Nigeria and to assess the effect of lead time on organizational performance in manufacturing Sector in Nigeria

\section{Review of Related Literature}

\subsection{Theoretical Framework}

\section{Inventory Management Theory}

The theory of inventory management was propounded by Nowicka-Skowron (2007). It emphasizes the role that management of logistics chains plays in material management and forecasting. The 
theory posits that the chain of movement of material and information depends to a large extent on the availability of materials and the quality of information at the disposal of the chain operator.

\subsection{Conceptual Framework}

Material management means the grouping of management functions supporting the complete cycle of material flow from the purchase and internal control of production, material is to the planning and control of work in process to the warehousing slipping and distribution of the finished products. The core of this concept is "material flow. This material flow has 3 phases upstream physical supply from the purchase, internal flow planning and control work in process and downstream flow the distribution of finished product. Carter (2005) defines material management as a concept which brings together under one manager the role of ascertaining the basic requirement of the organization with respect to the value chain of products and services at workplace.

Organisational performance has been defined differently by different scholars but some of them are in agreement that organisational performance describes the attainment of set goals. Organizational performance is the organization's ability to attain its goals by using resources in an efficient and effective manner. Performance relates to the ability to achieve goals or a specific mission (Jacobs et al., 2009). James (2012) carried out an empirical study on material management using chi square as a statistical tool and found efficient Materials Management is positively related to firm success. Thus, through a well-organized organization of production materials, cost effectiveness can be achieved in an organization.

\section{Methodology}

\subsection{Research Design}

Cross-sectional research design was used for the study. The population of the study area is made up of staffs that are directly in charge of handling of materials in the company; these departments are retail, logistic, warehouse, production. The staff of the retail department is made up of 122 employees, logistic unit has 25 employees, warehouse has 32 employees and production unit has 63 employees. This brings the population 242 respondents to be studied. The sample size for this study is thus, 242 comprising staff of Nigeria Brewery and the selected units that are involved in material management in Benue Brewery Makurdi. The staff of the retail department is made up of 122 employees, logistic unit has 25 employees, warehouse has 32 employees and production unit has 63 employees. Primary data was obtained for this work, through the use of structured questionnaire. In this study, the two most common types of validity, which are content and construct validity, were considered. While content validity was tested through the expert contributions from my team of supervisors, construct validity was tested with the use of Factor analytical tool that considered Kaiser-Meyer-Olkin (KMO) and Bartlett's Test of Sphericity. 
Table 1: Reliability Statistics

\begin{tabular}{|c|c|c|}
\hline Cronbach's AlphaCronbach's Alpha Based on Standardized Items N of Items \\
\hline .836 & .866 & 4 \\
\hline
\end{tabular}

Source: SPSS Result, 2019

Table 1 shows the reliability statistics which indicates that the Cronbach Alpha value is 0.836 . Reliability Cronbach Alpha statistics of 0.70 is considered adequate and reliable for social Science study. Hence, the variable of this study falls above the limit of a reliable instrument for this study.

\subsection{Model Specification}

Multiple regression analysis was employed to evaluate the magnitude and sign of the effect being studied as shown below:

$Y=\beta_{0}+\beta_{1} X_{1}+\beta_{2} X_{2}+\beta_{3} X_{3}+e$

$\mathrm{OGP}=f(\mathrm{INC}, \mathrm{STV}, \mathrm{LDT})$

Where,

INC $=$ Inventory Control

$\mathrm{STV}=$ Stock Valuation

LDT $=$ Lead Time

The explicit forms of the formula above are depicted below:

$\mathrm{OGP}=\mathrm{b} 0+\mathrm{b} 1 \mathrm{INC}+\mathrm{b} 2 \mathrm{STV}+\mathrm{b} 3 \mathrm{LDT}+\mathrm{Et}$

Where:

$\mathrm{b}_{0}=$ intercept value of the dependent variable

$\mathrm{e}=$ the random error term

b1, b2, b3 = the regression coefficients of the independent variables

$\mathrm{Et}=$ Error term

\section{A Priori Expectations}

(X_1) = Inventory Control; a priori expectation is positive

(X_2) = Stock Valuation; a priori expectation is positive

(X_3) = Lead Time; a priori expectation is positive

\subsection{Methods of Data Analysis}

The Statistical Package for Social Sciences (SPSS version 20.0). Multiple Regression Analyses was used to assess the nature and degree of effect between the dependent variable and a set of independent or predictor variables. However, standard error of the estimate was used to test the 4 hypotheses for this study. 
Decision Rule: The following decision rules were adopted for accepting or rejecting hypotheses: If the standard error of bi [S (bi) >1/2bi] we accept the null hypothesis, that is, we accept that the estimate bi is not statistically significant at the $5 \%$ level of significance. If the standard error of bi [S (bi) <1/2bi] we reject the null hypothesis, in other words, that is, we accept that the estimate b1 is statistically significant at the $5 \%$ level of significance.

\section{Result and Discussion}

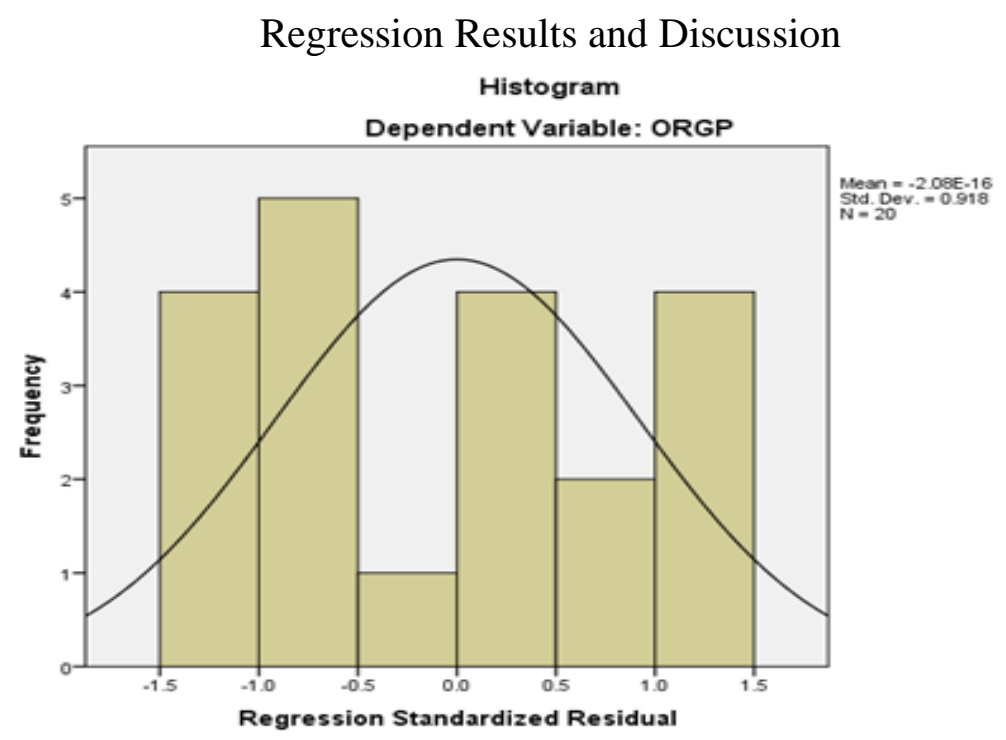

The figure above shows a histogram of the residuals with a normal curve superimposed. The residuals look close to normal, implying a normal distribution of data. Here is a plot of the residuals versus predicted dependent variable of Organizational Performance (ORGP). The pattern shown above indicates no problems with the assumption that the residuals are normally distributed at each level of the dependent variable and constant in variance across levels of $\mathrm{Y}$.

Table 2: Statistical Significance of the model ANOVA $^{\mathrm{a}}$

\begin{tabular}{|l|l|l|l|l|l|}
\hline Model & Sum of Squares & Df & Mean Square & F & Sig. \\
\hline Regression & 644.831 & 3 & 214.944 & 1.095 & $.038^{\mathrm{b}}$ \\
\hline 1 Residual & 3140.969 & 16 & 196.311 & & \\
\hline Total & 3785.800 & 19 & & & \\
\hline
\end{tabular}

a. Dependent Variable: ORGP

b. Predictors: (Constant), LDT, INC, STV

Source: SPSS 20.0 Result Output, 2019

The F-ratio in the ANOVA table above tests whether the overall regression model is a good fit for the data. The table shows that the independent variables statistically significantly predicts the dependent variable $\mathrm{F}(3,16)=1.095, \mathrm{p}<0.038 \mathrm{~b}$ (i.e., the regression model is a good fit of the data). 
Table 3: Model summary, Model Summary ${ }^{\mathrm{b}}$

\begin{tabular}{|c|c|c|c|c|c|}
\hline Model & R & R Square & Adjusted R Square & Std. Error of the Estimate & Durbin-Watson \\
\hline 1 & $.841 \mathrm{a}$ & .706 & .615 & .01109 & 2.646 \\
\hline
\end{tabular}

a. Predictors: (Constant), LDT, INC, STV

b. Dependent Variable: ORGP

Source: SPSS 20.0 Result Output, 2019

The coefficient of determination R2 for the study is 0.706 or $70.6 \%$. This indicates that $70.6 \%$ of the variations in the model can be explained by the explanatory variables of the model while $29.4 \%$ of the variation can be attributed to unexplained variation captured by the stochastic term.

Table 4: Regression coefficient

\begin{tabular}{|c|c|c|c|c|c|c|c|}
\hline \multirow[t]{2}{*}{ Model } & \multicolumn{2}{|c|}{$\begin{array}{l}\text { Unstandardized } \\
\text { Coefficients }\end{array}$} & \multirow{2}{*}{$\begin{array}{c}\begin{array}{c}\text { Standardized } \\
\text { Coefficients }\end{array} \\
\text { Beta }\end{array}$} & \multirow[t]{2}{*}{$\mathbf{t}$} & \multirow[t]{2}{*}{ Sig. } & \multicolumn{2}{|c|}{$\begin{array}{c}\text { Collinearity } \\
\text { Statistics }\end{array}$} \\
\hline & B & Std. Error & & & & Tolerance & VIF \\
\hline (Constant) & 2.701 & 17.940 & & 1.210 & .244 & & \\
\hline INC & .609 & .127 & .574 & 2.126 & .028 & .992 & 1.008 \\
\hline STV & .794 & .030 & .623 & 1.984 & .034 & .966 & 1.035 \\
\hline LDT & -.250 & .240 & -.241 & -2.043 & .031 & .972 & 1.029 \\
\hline
\end{tabular}

a. Dependent Variable: ORGP

Source: SPSS 20.0 Result Output, 2019

\subsection{Discussion of Findings}

The study indicated that lead time reduction is an important part of lean manufacturing. The model specification for Organizational Performance in the manufacturing industries in Nigeria establishes that a positive relationship exist between inventory control system and organizational performance and the relationship is statistically significant and in line with a priori expectation. This means that a unit increases in inventory control system will result to a corresponding increase in organizational performance by a margin of 57.4\%. This study is in line with that of Eyad (2006) who studied Construction Materials Management System for Gaza Strip Building Contractors. As shown by the results of the regression coefficients, a positive relationship exist between Stock valuation and organizational performance and the relationship is statistically significant and in line with a priori expectation. This means that a unit increases in Stock valuation will result to a corresponding increase in organizational performance by a margin of $71.0 \%$. This result is in line with the findings of James (2012) who studied the relationship between Materials Management and success of manufacturing firms. A negative relationship exists between lead time and organizational performance and the relationship is statistically significant and in line with a priori expectation. This means that a unit increases in long lead time will result to a corresponding decrease in organizational performance by a margin of $24.1 \%$. 


\section{Conclusions and Recommendations}

\section{Conclusion}

This study has shown that inventory control system and stock valuation have significant effect on the performance of the manufacturing sector in Nigeria. Thus, efficiency of the supply chain for materials need of the company brings about effective performance.

\section{Recommendations}

Based on the findings of this study, the following recommendations are made:

1) Since lead time was negatively related to organizational performance in our study, the management of the Nigerian Brewery should improve the lead time as it is highly significant to organizational.

2) Stock valuation made the highest contribution to organizational performance in our study and as a result, the management of the company under study should ensure that they employ all the methods of stock valuation in calculating the values of companies and their stocks

3) To enhance the inventory control system, a good inventory control system should analyze all inventory items for usage.

\section{References}

[1] Chase, R. B. Jacobs, R. F. Aquilano, N.J., \& Agarwal, N. K. (2009). Operations Management for competitive Advantage, 11th Ed. New Delhi Tata Mc-Graw Hill.

[2] Ibegbulem, A. B. and Okorie, C. (2005). Assessment of materials management and profitability of an organization. Journal of Policy and Development Studies Vol. 9 (3).

[3] James, M. U. (2012) studied the relationship between Materials Management and success of manufacturing firms: The Case of the Nigerian Bottling Company Plc. International Journal of Economics and Management Sciences Vol. 1, No. 7,

[4] Lee, L. and Dobler D. (1997). Purchasing and Materials. TMH Publishers Inc. Pp. 138.

[5] Eyad, A. E. (2006). Construction Materials Management System for Gaza Strip Building Contractors. A Master of Science Thesis Submitted to the Islamic University of Gaza Deanery of Graduate Studies Faculty of Engineering Construction Management Program. Online at https://bit.ly/38noRov

[6] Okoro, A. B. (2019). Material Management and Performance in Nigerian Manufacturing Sector. Journal of Supply Chain Management. 2(1), 15-27

[7] Nowicka-Skowron M., (2007). Cost Aspects in Supply Chain Management, [in:] Financnilogisticke rizeni - 2007. Sbornik referatu z mezinarodni konference. Ceska republika, Malenowice 2007, p.538 